\section{(2) \\ BRAZIULIAN JOURNAL \\ OF MEDICAL AND BIOLOGICAL RESEARCH}

www.bjournal.com.br
ISSN 0100-879X

Volume 45 (5) 376-472 May 2012

BIOMEDICAL SCIENCES

AND

CLINICAL INVESTIGATION

Braz J Med Biol Res, May 2012, Volume 45(5) 436-443

doi: 10.1590/S0100-879X2012007500052

Participation of the GABAergic system in the anesthetic effect of Lippia alba (Mill.) N.E. Brown essential oil

C.G. Heldwein, L.L. Silva, P. Reckziegel, F.M.C. Barros, M.E. Bürger, B. Baldisserotto, C.A. Mallmann, D. Schmidt, B.O. Caron and B.M. Heinzmann

The Brazilian Journal of Medical and Biological Research is partially financed by

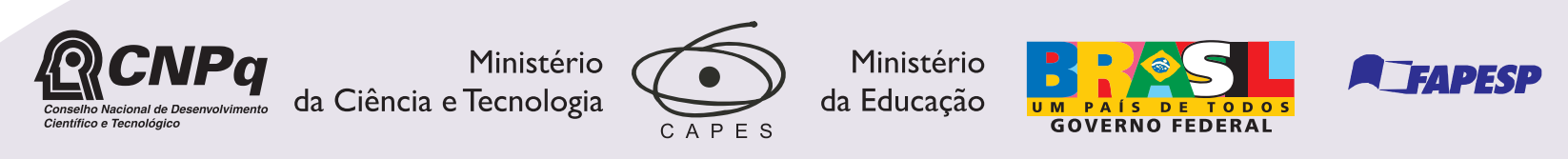

Institutional Sponsors

Scie/O
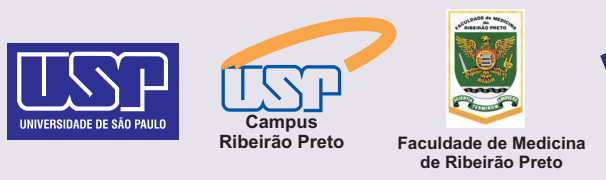

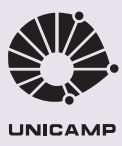

SHIMADZU

Associaçäo
Fundo de Incentivo
à Pesquisa

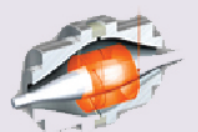




\title{
Participation of the GABAergic system in the anesthetic effect of Lippia alba (Mill.) N.E. Brown essential oil
}

\author{
C.G. Heldwein ${ }^{1}$, L.L. Silva ${ }^{1}$, P. Reckziegel ${ }^{2}$, F.M.C. Barros ${ }^{1}$, M.E. Bürger², \\ B. Baldisserotto ${ }^{2}$, C.A. Mallmann ${ }^{3}$, D. Schmidt ${ }^{4}$, B.O. Caron 4 \\ and B.M. Heinzmann ${ }^{1}$ \\ ${ }^{1}$ Departamento de Farmácia Industrial, Universidade Federal de Santa Maria, Santa Maria, RS, Brasil \\ 2Departamento de Fisiologia e Farmacologia, Universidade Federal de Santa Maria, Santa Maria, RS, Brasil \\ ${ }^{3}$ Departamento de Medicina Veterinária Preventiva, Universidade Federal de Santa Maria, Santa Maria, RS, Brasil \\ ${ }^{4}$ Departamento de Ciências Agronômicas e Ambientais, Universidade Federal de Santa Maria, \\ Campus de Frederico Westphalen, Frederico Westphalen, RS, Brasil
}

\begin{abstract}
The objective of this study was to identify the possible involvement of the GABAergic system in the anesthetic effect of Lippia alba essential oil (EO). We propose a new animal model using silver catfish (Rhamdia quelen) exposed to an anesthetic bath to study the mechanism of action of EO. To observe the induction and potentiation of the anesthetic effect of EO, juvenile silver catfish $(9.30 \pm 1.85 \mathrm{~g} ; 10.15 \pm 0.95 \mathrm{~cm} ; \mathrm{N}=6)$ were exposed to various concentrations of $L$. alba EO in the presence or absence of diazepam [an agonist of high-affinity binding sites for benzodiazepinic (BDZ) sites coupled to the $\mathrm{GABA}_{A}$ receptor complex]. In another experiment, fish $(\mathrm{N}=6)$ were initially anesthetized with the $\mathrm{EO}$ and then transferred to an anesthetic-free aquarium

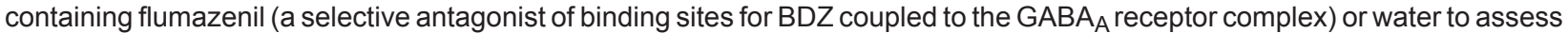
recovery time from the anesthesia. In this case, flumazenil was used to observe the involvement of the GABA-BDZ receptor in the EO mechanism of action. The results showed that diazepam potentiates the anesthetic effect of EO at all concentrations tested. Fish exposed to diazepam and EO showed faster recovery from anesthesia when flumazenil was added to the recovery bath (12.0 \pm 0.3 and $7.2 \pm 0.7$, respectively) than those exposed to water ( $9.2 \pm 0.2$ and $3.5 \pm 0.3$, respectively). In conclusion, the results demonstrated the involvement of the GABAergic system in the anesthetic effect of $L$. alba EO on silver catfish.
\end{abstract}

Key words: False-melissa; Silver catfish; Benzodiazepines; Flumazenil; GABA

\section{Introduction}

Various substances or combinations of substances, such as barbiturates, quinaldine, tricaine methanesulfonate (MS 222), metomidate, etomidate, and benzocaine, have been used to induce anesthesia in different fish species to minimize stress in these animals (1-4). However, in recent years, natural products such as clove oil and isoeugenol (AQUI-S), have demonstrated similar or superior effectiveness with less toxicity to fish compared to anesthetic drugs $(5,6)$.

Lippia alba (Mill.) N.E. Brown, known as "false-melissa" in Brazil, is an aromatic shrub whose great chemical variability also leads to variations in its pharmacological activity. In Brazil, three main chemotypes are reported and classi- fied according to their major constituent as citral, carvone and linalool (7).

This plant has been commonly used for its sedative properties, which have been demonstrated in some rodent studies $(7,8)$. Recently, the anesthetic effect of $L$. alba essential oil (EO) was demonstrated on silver catfish (Rhamdia quelen). The EO of $L$. alba is considered to be a novel natural sedative and anesthetic agent that can be potentially used in aquaculture practices due to its ability to reduce stress in fish with a consequent reduction of economic losses in fish culture (9).

Most anesthetics exert their effects by regulating the gamma-aminobutyric acid (GABA) receptor complex, as

Correspondence: B.M. Heinzmann, Departamento de Farmácia Industrial, Universidade Federal de Santa Maria, Avenida Roraima, 1000, Prédio 26, 97105-900 Santa Maria, RS, Brasil. Fax: +55-55-3220-8248. E-mail: berta.heinzmann@gmail.com

Received August 17, 2011. Accepted March 20, 2012. Available online April 5, 2012. Published May 7, 2012. 
GABA is the main inhibitory neurotransmitter in the central nervous system (10). Synaptic GABA release activates $G_{B B A}$ and $G A B A_{C}$ ionotropic receptors as well as the metabotropic receptor $\operatorname{GABA}_{B}(11,12)$. $\mathrm{GABA}_{A}$ receptors have been implicated in the majority of GABAergic signaling in mammals. High-affinity binding sites for benzodiazepines (BDZ) are known as "central BDZ receptors", and these compounds exert their pharmacological action by allosteric modulation in these regions. The activation of these sites enhances GABA-induced chloride ion flux, resulting in hyperpolarization and central depression. Expression of the GABAergic system seems to be conserved among vertebrates, from fishes to mammals (13). This system has been detected in certain parts of the zebrafish brain $(13,14)$ and could be involved in their response to anesthetics. The mechanism of action of $L$. alba EO has not yet been elucidated. In order to determine the mechanism of the anesthetic effect of EO, we propose a new animal model using silver catfish to examine the involvement of the GABAergic mechanism in fish exposed to an anesthetic bath.

\section{Material and Methods}

\section{Plant material}

L. alba was grown at the CESNORS/UFSM Campus, Frederico Westphalen, southern Brazil (geographically situated at $27^{\circ} 23^{\prime} 26^{\prime \prime}$ South, $53^{\circ} 25^{\prime} 43^{\prime \prime}$ West and $461 \mathrm{~m}$ above sea level). The species was identified by Gilberto Dolejal Zanetti, Department of Industrial Pharmacy, UFSM, and a voucher specimen (SMDB No. 10050) was deposited in the herbarium of the Department of Biology, UFSM.

\section{EO extraction and analysis}

EO was obtained from fresh $L$. alba leaves using the hydrodistillation process with a Clevenger type apparatus (15) for $2 \mathrm{~h}$. The yield was calculated as w/w (\%). The EO was stored at $-20^{\circ} \mathrm{C}$ until composition analysis and testing. For comparison purposes, the composition of the EO used in this study (EO1) and the corresponding data for the EO used by Cunha et al. (9) (EO2) are presented in Table 1. The compositions of both EOs were analyzed by GC-MS.

GC-MS TIC analysis was performed using an Agilent-6890 gas chromatograph coupled to an Agilent 5973 mass selective detector, under the following conditions: HP-5MS column (5\% phenyl-95\% methylsiloxane, $30 \mathrm{~m} \mathrm{x}$ $0.25 \mathrm{~mm} \times 0.25 \mu \mathrm{m})$; El-MS: $70 \mathrm{eV}$; operating conditions: split inlet, $1: 100$; temperature program, $40-260^{\circ} \mathrm{C} ; 40^{\circ} \mathrm{C}$ for $4 \mathrm{~min}$; ramp rate, $4^{\circ} \mathrm{C} / \mathrm{min}$; carrier gas, He; flow rate, $1 \mathrm{~mL} /$ min; injector and detector temperature, $220^{\circ} \mathrm{C}$; interface temperature, $250^{\circ} \mathrm{C}$.

The constituents of the EOs were identified by comparison of the mass spectra with a mass spectral library (16) and by comparison of the Kovats retention index with literature data (17).

\section{Animals}

Juvenile silver catfish $(9.30 \pm 1.85 \mathrm{~g} ; 10.15 \pm 0.95 \mathrm{~cm})$ were housed in continuously aerated 250 -L tanks (18.46 $\pm 0.51^{\circ} \mathrm{C} ; \mathrm{pH} 7.47 \pm 0.073$; total ammonia levels, 0.0883 $\mathrm{mg} / \mathrm{L}$; dissolved oxygen levels, $8.84 \pm 0.37 \mathrm{mg} / \mathrm{L})$. A semistatic system was used, and $50 \%$ of the water volume was changed daily. The fish received a commercial diet (Vicente Alimentos S.A., Brazil) with $3.5 \% \mathrm{Ca}^{2+}, 28.0 \%$ crude protein and $3500 \mathrm{kcal} / \mathrm{kg}$ digestible energy, as stated by the manufacturer. Juveniles were fed once a day and were fasted for a period of $24 \mathrm{~h}$ prior to the experiments. The water parameters were measured before the experiments. Dissolved oxygen and temperature were measured with a YSI oxygen meter (Model Y5512; YSI Inc., USA). The pH was verified with a DMPH-2 $\mathrm{pH}$ meter (Digimed, Brazil) and nesslerization was used to verify total ammonia levels according to the method of Greenberg et al. (18).

The experiments were approved by the Ethics and Animal Welfare Committee of Universidade Federal de Santa Maria (protocol No. 23081.014553/2009-39).

\section{Standardization of the test conditions}

The depressor effect of anesthetics in fish was evaluated by the method of Schoettger and Julin (19). The method involves six stages, in which the following parameters were observed: light and deep sedation (stages 1 and 2, respectively), partial and total loss of equilibrium (stages $3 a$ and b, respectively), deep anesthesia (stage 4) and medullar collapse (stage 5).

Prior to the potentiation test, diazepam concentration (BDZ) (DEG, Brazil) was standardized. Fish were transferred to $1-L$ aquaria containing 25,100 , and $150 \mu \mathrm{M} \mathrm{BDZ}$, previously solubilized in $0.033 \%$ Tween 80 . To evaluate the time required to reach the different stages of anesthesia induction, three juveniles were used for each concentration tested, and each juvenile was used only once, according to the method of Schoettger and Julin (19). The maximum time of observation was $30 \mathrm{~min}$. After induction, animals were transferred to an anesthetic-free aquarium to assess the recovery time.

For tests of the reversal of anesthetic effects, the flumazenil (Flumazil ${ }^{\circledR}$, Cristália, Brazil) concentration in the recovery bath was also standardized and used to observe the involvement of the GABA-BDZ receptor in the mechanism of action of EO. Fish ( $N=6)$ were subjected to sedation induction with $150 \mu \mathrm{M} \mathrm{BDZ}$ in 1-L aquaria. After induction, the animals were divided into two groups: one group was transferred to an anesthetic-free aquarium with water while the second group was placed in an aquarium containing flumazenil. In both groups, fish behavior was scored after $1,5,10,15$, and $20 \mathrm{~min}$, as described in Table 2. After 20 $\mathrm{min}$, the sum of scores for each fish was calculated. When agitation was verified in a given fish, we added 0.5 to its score. Each observation included an external stimulus while observing the fish; undisturbed animals tend to remain 
Table 1. Chemical constituents of Lippia alba (Mill.) N.E. Brown essential oil used in the present study (EO1) and by Cunha et al. (9) (EO2).

\begin{tabular}{|c|c|c|c|c|c|c|c|}
\hline \multirow[t]{2}{*}{ Components } & \multicolumn{2}{|c|}{ Relative \% } & \multicolumn{2}{|c|}{ Retention time (min) } & \multicolumn{2}{|c|}{ IK calculated } & \multirow[t]{2}{*}{ IK literature } \\
\hline & EO1 & EO2 & EO1 & EO2 & EO1 & EO2 & \\
\hline a-thujone & - & 0.04 & - & 10.49 & - & 925 & $930^{a}$ \\
\hline$\alpha$-pinene & 0.13 & 0.23 & 10.10 & 10.75 & 911 & 931 & $939^{a}$ \\
\hline camphene & 0.20 & 0.50 & 10.67 & 11.42 & 927 & 947 & $954^{a}$ \\
\hline a-phellandrene & 1.32 & - & 11.76 & - & 954 & - & $1003^{a}$ \\
\hline sabinene & 0.22 & 1.90 & 11.83 & 12.42 & 956 & 972 & $975^{a}$ \\
\hline 1-octen-3-ol & 0.10 & - & 12.15 & - & 964 & - & $979^{a}$ \\
\hline myrcene & 0.84 & 1.37 & 12.58 & 13.17 & 974 & 990 & $991^{a}$ \\
\hline limonene & 0.48 & 1.11 & 14.06 & 14.75 & 1007 & 1029 & $1029^{a}$ \\
\hline 1,8-cineole & 9.11 & 8.59 & 14.18 & 14.95 & 1011 & 1034 & $1031^{a}$ \\
\hline$\beta$-ocimene, $Z$ & 0.09 & 0.13 & 14.52 & 15.09 & 1021 & 1038 & $1037^{a}$ \\
\hline$\beta$-ocimene, $E$ & 0.67 & 0.62 & 14.93 & 15.49 & 1032 & 1048 & $1050^{a}$ \\
\hline $\mathrm{Y}$-terpinene & 0.03 & 0.04 & 15.30 & 15.94 & 1041 & 1059 & $1060^{a}$ \\
\hline sabinene hydrate, $Z$ & 0.14 & - & 15.66 & - & 1051 & - & $1070^{a}$ \\
\hline linalool oxide, $E$ & - & 0.47 & - & 16.51 & - & 1073 & $1073^{a}$ \\
\hline isoterpinolene & - & 0.48 & - & 16.97 & - & 1085 & $1088^{a}$ \\
\hline linalool oxide, $Z$ & 0.05 & 0.16 & 15.92 & 17.15 & 1057 & 1089 & $1087^{a}$ \\
\hline terpinolene & 0.22 & - & 16.49 & - & 1071 & - & $1089^{a}$ \\
\hline sabinene hydrate, $E$ & 0.02 & - & 16.94 & - & 1082 & - & $1098^{a}$ \\
\hline \multirow[t]{2}{*}{ linalool } & 59.66 & 37.47 & 17.33 & 18.00 & 1091 & 1111 & $1097^{a}$ \\
\hline & & & & & & & $1094^{b}$ \\
\hline 3-hexenyl isobutanoate, $Z$ & - & 0.03 & - & 19.20 & - & 1143 & $1147^{a}$ \\
\hline hotrienol & 0.10 & - & 17.38 & - & 1092 & - & $1104^{b}$ \\
\hline 1,3,8-p-menthatriene & 0.07 & - & 17.91 & - & 1106 & - & $1110^{a}$ \\
\hline 6-camphenol & 0.04 & - & 18.08 & - & 1111 & - & $1114^{a}$ \\
\hline \multirow[t]{2}{*}{ camphor } & 3.15 & 6.87 & 18.76 & 19.53 & 1130 & 1152 & $1146^{a}$ \\
\hline & & & & & & & $1144^{b}$ \\
\hline chrysanthenol, $E$ & 0.03 & - & 19.23 & - & 1143 & - & $1164^{a}$ \\
\hline $\begin{array}{l}\text { bicyclo[2.2.1] heptan-3-one,6,6- } \\
\text { dimethyl, 2-methylene }\end{array}$ & 0.29 & - & 19.46 & - & 1149 & - & $1149^{b}$ \\
\hline pinocarvone & - & 0.66 & - & 20.03 & - & 1165 & $1165^{a}$ \\
\hline borneol & 0.37 & 1.06 & 19.58 & 20.45 & 1153 & 1176 & $1169^{a}$ \\
\hline$p$-mentha-1,5-dien-8-ol & 0.65 & - & 19.65 & - & 1155 & - & $1170^{a}$ \\
\hline neoiso-isopulegol & 0.09 & - & 19.96 & - & 1163 & - & $1171^{a}$ \\
\hline terpinen-4-ol & 0.07 & - & 20.03 & - & 1165 & - & $1177^{a}$ \\
\hline a-terpineol & 0.58 & 0.88 & 20.56 & 21.31 & 1178 & 1199 & $1189^{a}$ \\
\hline myrtenal & 0.11 & 0.09 & 20.76 & 21.25 & 1183 & 1198 & $1196^{a}$ \\
\hline 2,6-dimethyl-3,5,7-octatrien-2-ol, Z, Z & 0.64 & - & 21.01 & - & 1190 & - & $1090^{b}$ \\
\hline 2,6-dimethyl-3,5,7-octatrien-2-ol, $E, E$ & 1.65 & - & 21.31 & - & 1197 & - & $1134^{b}$ \\
\hline verbenone & - & 0.36 & - & 21.74 & - & 1211 & $1205^{a}$ \\
\hline trans-carveol & - & 2.00 & - & 21.88 & - & 1215 & $1217^{a}$ \\
\hline citronellol & 0.02 & - & 22.04 & - & 1219 & - & $1226^{a}$ \\
\hline neral (citral b) & 0.15 & - & 22.48 & - & 1232 & - & $1238^{a}$ \\
\hline geranial (citral a) & 0.14 & - & 23.57 & - & 1263 & - & $1267^{a}$ \\
\hline isobornyl acetate & 0.07 & 0.16 & 24.11 & 24.36 & 1278 & 1285 & $1286^{a}$ \\
\hline
\end{tabular}

Continued on next page 
Table 1 continued.

\begin{tabular}{|c|c|c|c|c|c|c|c|}
\hline \multirow[t]{2}{*}{ Components } & \multicolumn{2}{|c|}{ Relative \% } & \multicolumn{2}{|c|}{ Retention time (min) } & \multicolumn{2}{|c|}{ IK calculated } & \multirow[t]{2}{*}{ IK literature } \\
\hline & EO1 & EO2 & EO1 & EO2 & EO1 & EO2 & \\
\hline myrtenyl acetate & - & 0.03 & - & 25.70 & - & 1325 & $1327^{a}$ \\
\hline$\delta$-elemene & 0.03 & 0.03 & 25.93 & 26.03 & 1332 & 1335 & $1338^{a}$ \\
\hline exo-2-hydroxycineolacetate & 0.11 & - & 26.12 & - & 1338 & - & $1354^{b}$ \\
\hline$\alpha$-cubebene & 0.01 & 0.02 & 26.36 & 26.42 & 1345 & 1346 & $1351^{a}$ \\
\hline cyclosativene & - & 0.04 & - & 27.15 & - & 1368 & $1371^{a}$ \\
\hline$\alpha$-copaene & 0.19 & 0.38 & 27.26 & 27.38 & 1373 & 1375 & $1377^{a}$ \\
\hline$\beta$-bourbonene & 0.17 & 0.12 & 27.58 & 27.64 & 1382 & 1383 & $1388^{a}$ \\
\hline$\beta$-cubebene & - & 0.19 & - & 27.78 & - & 1387 & $1388^{a}$ \\
\hline$\beta$-elemene & 1.32 & 0.69 & 27.84 & 27.84 & 1390 & 1389 & $1391^{a}$ \\
\hline a-gurjenene & 0.023 & 0.07 & 28.43 & 28.38 & 1407 & 1406 & $1410^{a}$ \\
\hline$\beta$-caryophyllene & 2.84 & 4.09 & 28.77 & 28.84 & 1419 & 1420 & $1419^{a}$ \\
\hline$\beta$-copaene & 0.11 & 0.15 & 29.07 & 29.12 & 1429 & 1429 & $1432^{a}$ \\
\hline Y-elemene & 0.91 & - & 29.22 & - & 1434 & - & $1437^{a}$ \\
\hline a-humulene & 0.364 & 0.89 & 29.88 & 29.95 & 1455 & 1456 & $1455^{a}$ \\
\hline$\beta$-farnesene, $E$ & 0.21 & - & 29.97 & - & 1458 & - & $1458^{b}$ \\
\hline \multirow[t]{2}{*}{ allo-aromadendrene } & 0.17 & 0.28 & 30.12 & 30.07 & 1463 & 1460 & $1460^{a}$ \\
\hline & & & & & & & $1459^{b}$ \\
\hline Y-muurolene & - & 0.16 & - & 30.58 & - & 1476 & $1480^{a}$ \\
\hline \multirow[t]{2}{*}{ a-amorphene } & 0.11 & - & 30.66 & - & 1479 & - & $1485^{a}$ \\
\hline & & & & & & & $1480^{b}$ \\
\hline \multirow[t]{2}{*}{ germacrene D } & 3.78 & 5.40 & 30.82 & 30.80 & 1484 & 1483 & $1485^{a}$ \\
\hline & & & & & & & $1486^{b}$ \\
\hline 4-epi-cubebol & 0.09 & - & 31.23 & - & 1497 & - & $1494^{a}$ \\
\hline bicyclogermacrene & 0.14 & 0.27 & 31.28 & 31.19 & 1499 & 1495 & $1500^{a}$ \\
\hline a-muurolene & 0.23 & 0.58 & 31.40 & 31.28 & 1502 & 1498 & $1500^{a}$ \\
\hline germacrene A & - & 0.88 & - & 31.58 & - & 1508 & $1509^{a}$ \\
\hline 10-epi-cubebol & 0.42 & - & 31.89 & - & 1520 & - & $1535^{a}$ \\
\hline Y-cadinene & 0.36 & 0.06 & 32.13 & 31.73 & 1529 & 1513 & $1514^{a}$ \\
\hline$\delta$-cadinene & - & 1.16 & - & 31.88 & - & 1518 & $1523^{a}$ \\
\hline nerolidol, Z & 0.18 & - & 32.60 & - & 1545 & - & $1533^{a}$ \\
\hline germacrene B & - & 3.65 & - & 33.14 & - & 1561 & $1561^{a}$ \\
\hline nerolidol, $E$ & - & 0.58 & - & 33.23 & - & 1564 & $1563^{a}$ \\
\hline germacrene D-4-ol & 1.05 & 2.56 & 33.79 & 33.71 & 1585 & 1580 & $1576^{a}$ \\
\hline caryophyllene oxide & 0.62 & 0.91 & 34.03 & 33.84 & 1593 & 1584 & $1583^{a}$ \\
\hline viridiflorol & 0.06 & - & 34.65 & - & 1616 & - & $1593^{a}$ \\
\hline humulene epoxide II & - & 0.15 & - & 34.64 & - & 1612 & $1608^{a}$ \\
\hline 1,10-di-epi-cubenol & - & 0.12 & - & 34.79 & - & 1617 & $1619^{a}$ \\
\hline$\tau$-cadinol & - & 0.17 & - & 35.56 & - & 1645 & $1640^{a}$ \\
\hline$\tau$-muurolol & 0.21 & 0.53 & 35.76 & 35.62 & 1656 & 1647 & $1642^{\mathrm{a}}$ \\
\hline$\alpha$-muurolol & - & 0.18 & - & 35.70 & - & 1650 & $1646^{a}$ \\
\hline 14-hydroxy-9-epi-caryophyllene, $E$ & 0.17 & - & 35.99 & - & 1664 & - & $1670^{a}$ \\
\hline a-cadinol & 0.25 & 0.62 & 36.14 & 35.96 & 1670 & 1659 & $1654^{a}$ \\
\hline 14-hydroxy-a-muurolene & 0.26 & - & 39.11 & - & 1780 & - & $1780^{a}$ \\
\hline$\Sigma(\%)$ of identified compounds & 95.92 & 90.18 & & & & & \\
\hline
\end{tabular}

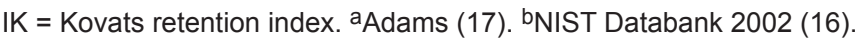


stationary. This stimulation consisted of successive hits with a glass rod on the bottom of the aquarium.

\section{Experiment 1: Potentiation with BDZ}

Various concentrations (50, 100, and $300 \mu \mathrm{L} / \mathrm{L}$ ) of $L$. alba EO (previously diluted $1: 10$ in ethanol) were added along with $\mathrm{BDZ}(150 \mu \mathrm{M})$ to the $1-\mathrm{L}$ aquaria. Six fish were tested individually for each concentration. Evaluation of BDZ with ethanol (EO vehicle), EO and both vehicles alone (Tween 80 and ethanol at the same proportions used) was also performed. The stages of anesthesia induction and recovery time were evaluated according to the protocol described in the standardization of the test conditions.

\section{Experiment 2: Reversal of anesthetic effects}

The same protocol described in the standardization of the test conditions was repeated with $L$. alba EO at 300 $\mu \mathrm{L} / \mathrm{L}$. After induction, fish $(\mathrm{N}=6)$ were divided into two groups: one group was transferred to an anesthetic-free aquarium with water, and the second group was placed in an aquarium containing $5 \mu \mathrm{M}$ flumazenil. The results were scored (Table 2) after 1, 5, 10, 15, and $20 \mathrm{~min}$ and are reported as the sum of scores.

\section{Statistical analyses}

All data were subjected to a Levene test to determine the homogeneity of variances. One-way ANOVA followed by the Tukey test or Kruskal-Wallis and Mann-Whitney tests were used in the potentiation test when appropriate (SPSS version 17.0). Results of the study of reversal of the anesthetic effects were compared by two-way ANOVA and the Tukey test with Sigma Plot (version 11.0). Significance was set at the level of $95 \%(P<0.05)$. Data are reported as means \pm SEM.

\section{Results}

\section{EO composition}

The EO yield (w/w) was $0.35 \%$ based on its mass in relation to the mass of plant material. The chemical composition of the EO used in this study (EO1) is similar to the corresponding data of the EO used by Cunha et al. (9) (EO2). However, EO1 contained 62 identified compounds, whereas EO2 contained 48 compounds. Monoterpene compounds represent $81.53 \%$ of EO1 and $65.22 \%$ of EO2, and sesquiterpenes represent 14.29 and $24.93 \%$ of EO1 and EO2, respectively. The major components of EO1 and EO2 were linalool (59.66 and $37.47 \%$, respectively), 1,8-cineole (9.11 and 8.59\%), camphor (3.15 and 6.87\%), germacrene $\mathrm{D}$ (3.78 and $5.40 \%)$, and $\beta$-cariophyllene (2.84 and $4.09 \%$; Table 1).

\section{Standardization of the test conditions}

Fish exposed to $25 \mu \mathrm{M} B D Z$ reached deep sedation (stage 2), whereas those exposed to 100 and $150 \mu \mathrm{M}$ presented total loss of equilibrium (stage $3 a$ ). Silver catfish exposed to the concentrations of diazepam used in this study did not reach stage 4 of anesthesia. The concentration of $150 \mu \mathrm{M}$ was chosen for the subsequent tests because fish reached stage $3 a$ within a relatively short period of time (about $9 \mathrm{~min}$ ) and showed a longer recovery time (about 18 min) compared to those exposed to $100 \mu \mathrm{M} \mathrm{BDZ}$ (induction time approximately $22 \mathrm{~min}$; recovery time approximately 5 $\min )$. A longer recovery time was required to better determine the efficacy of the antagonist in the reversal of the anesthetic effects.

The flumazenil concentration was standardized by testing $0.05,1.0$, and $5.0 \mu \mathrm{M}$ of this GABA receptor antagonist. Scores of recovery from anesthesia in fish exposed to $1 \mu \mathrm{M}$ $(10.2 \pm 0.6)$ and $5 \mu \mathrm{M}$ flumazenil $(9.3 \pm 0.6)$ were significantly different from those of control animals $(8.2 \pm 0.4$ and 7.8 \pm 0.4 , respectively) with $P<0.05$. Fish that recovered in water with $0.05 \mu \mathrm{M}$ flumazenil showed scores $(8.5 \pm 0.3)$ that were not significantly different from animals that recovered in water alone $(7.8 \pm 0.3)$. In this test, higher scores indicate faster recovery from the anesthesia.

The application of ethanol alone did not produce an anesthetic effect.

\section{Experiment 1: Potentiation with BDZ}

The combination of BDZ+EO of $L$. alba significantly reduced the time required to reach anesthesia compared to the EO alone. BDZ potentiated deep sedation (stage 2) and total loss of equilibrium (stage $3 a$ ) of the animals exposed to $L$. alba EO, except in the case of fish exposed to 100 $\mu \mathrm{L} / \mathrm{L}$ regarding stage 2 (Figure $1 \mathrm{~A}$ and $\mathrm{B}$ ). Given alone, 50 $\mu \mathrm{L} / \mathrm{L}$ EO only led to stage $3 a$ anesthesia, but, in combination with BDZ, it led to stage 4 anesthesia. The highest EO concentrations evaluated (100 and $300 \mu \mathrm{L} / \mathrm{L}$ ) also led to stage 4 , and combined treatment with BDZ decreased the time required to reach this stage (Figure $1 \mathrm{C}$ ). The time of recovery from $L$. alba EO anesthesia was significantly 
longer in fish exposed to $300 \mu \mathrm{L} / \mathrm{L}$ than to the lower $\mathrm{EO}$ concentrations, and the combination of BDZ+EO of $L$. alba did not change the recovery time (Figure 1D).

\section{Experiment 2: Reversal of the anesthetic effects}

Fish anesthetized with $L$. alba EO $(300 \mu \mathrm{L} / \mathrm{L})$ or exposed to BDZ presented significantly higher recovery score sums when recovering in water with flumazenil than in water alone $(P<0.05$; Figure 2). Therefore, recovery was faster in water containing flumazenil.

\section{Discussion}

The EO used in this study, as well as that used by Cunha et al. (9), was obtained from $L$. alba chemotype linalool, which was previously described by Frighetto et al. (20) and Duarte et al. (21). When comparing the composition of the EO used in this study to that used by Cunha et al. (9), we observed similar chemical compositions. Although there were discrepancies between our results and previous results regarding the percentages of the major EO components, the effects observed for the natural anesthetic mixture without BDZ were as expected, and we demonstrated that the EO used in our assays can reproduce the effect observed by Cunha et al. (9). However, the time to achieve stage 4 was longer in the present study than in the study by Cunha et al. (9). This disparity can be explained by the different percentage of some compounds, including the major compound (linalool).

GABA complex ligands include agonists, antagonists and modulators. Typically, some behavioral effects that result from positive allosteric modulators of $G_{A B A}$ receptors are anxiolysis, cessation of convulsions, sedation, and general anesthesia (22-24). All of these activities have been described for $L$. alba EO (7-9,25,26). Additionally, Vale et al. (7) verified that EOs of $L$. alba belonging to limonene and citral chemotypes have similar pharmacological profiles to those of BDZ, indicating that they might interact with the binding sites for benzodiazepines located adjacent to the $\mathrm{GABA}_{\mathrm{A}}$ receptor complex $(11,12)$.

This potential GABAergic involvement was evaluated by the potentiation of the anesthetic effect of $L$. alba EO with BDZ. The best result observed in the present study was produced by the induction of anesthesia with the lowest concentration of EO tested. This clearly indicates the synergism of the compounds and the possibility for the combined use of these products to reduce the concentration of both in fish anesthesia. Additionally, the results indicate that the EO of $L$. alba has some effect on the GABA-receptor complex. This finding was confirmed by the faster recovery period observed with flumazenil treatment after the EO bath. In the animal model developed in the present study, the recovery scores recorded after 20 min of observation were summed and the values were converted to percentages. In these
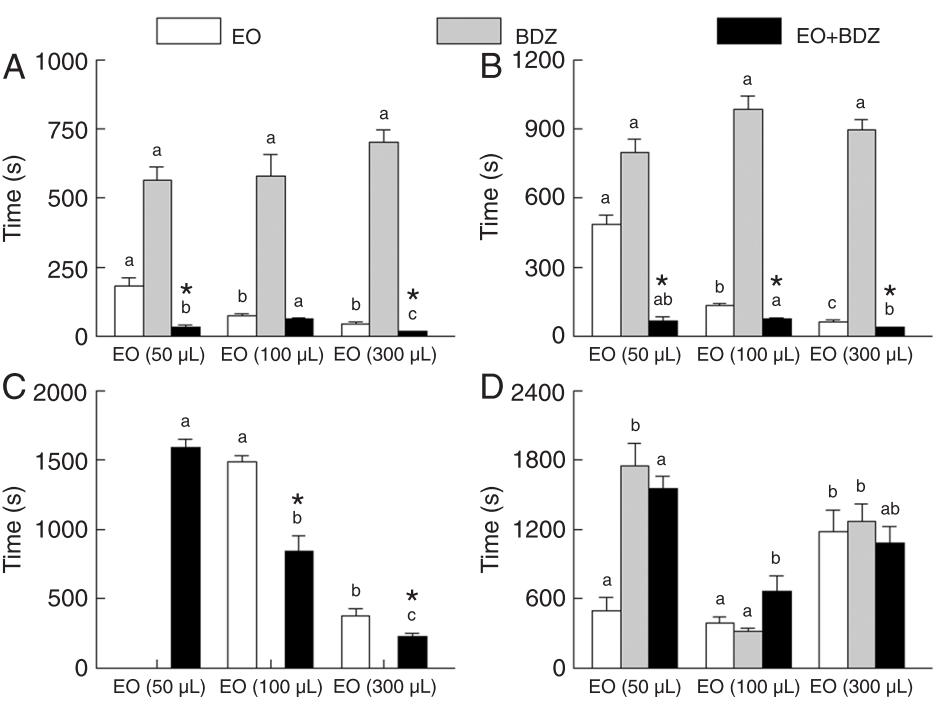

Figure 1. Time required for the induction of and recovery from anesthesia using the essential oil of Lippia alba (EO1), diazepam (BDZ) and the essential il + diazepam (EO+BDZ) combination in silver catfish juveniles. Stages acto reach different stages of anesthesia: $A$, stage 2 (deep sedation); $B$, time. Different letters indicate significant differences between concentrations in the same group: EO, BDZ or EO+BDZ. ${ }^{*} P<0.05$ compared to the EO group tested at the same concentration (one-way ANOVA followed by the Tukey test or Kruskal-Wallis and Mann-Whitney tests).

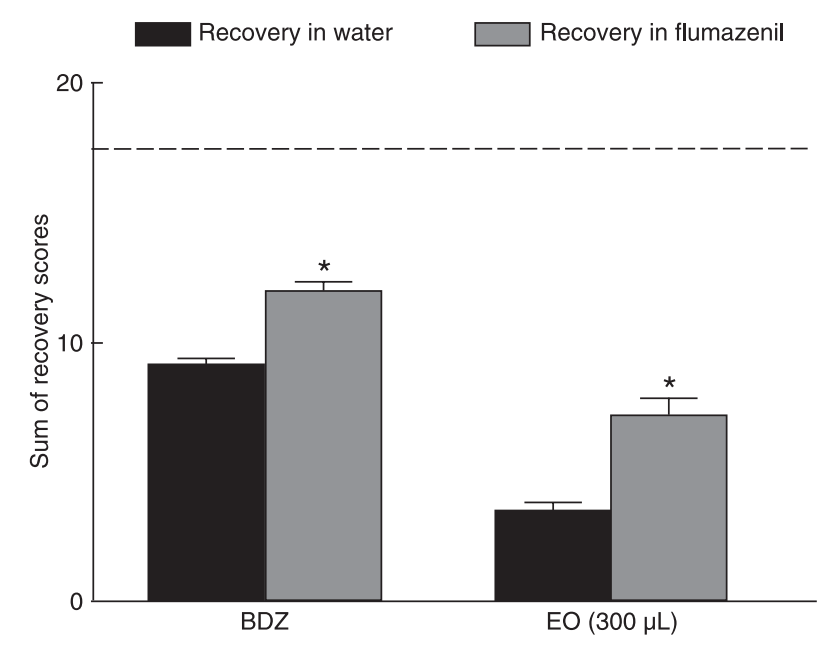

Figure 2. Sum of the recovery scores after anesthesia of Rhamdia quelen silver catfish. ${ }^{*} \mathrm{P}<0.05$ compared to recovery in water (two-way ANOVA and Tukey test). The maximum score possible (17.5) is indicated by the dotted line. 
calculations, $100 \%$ corresponded to the maximum score possible (17.5). Fish exposed to EO showed percent recovery scores of $40.91 \%$ with flumazenil and $20.0 \%$ in water. Similarly, for the standard drug (BDZ), we observed percent recovery scores of $68.57 \%$ in the presence of flumazenil and of $52.34 \%$ under control conditions (water).

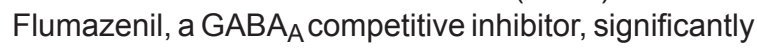
accelerated recovery from BDZ- and EO-induced depression, suggesting the involvement of $\mathrm{GABA}_{A}$ receptors in the anesthetic effect of $L$. alba EO in silver catfish. However, the existence of other possible neurochemical mechanisms, such as anti-nicotinic (27) and anti-glutamatergic (28) activity, cannot be excluded on the basis of the current results.

The literature describes the central nervous system activity of some essential oils, including their effect on the GABAergic system (29-32). Some natural products, such as terpenoids, which are the main components of the $E O$ tested, have exhibited effects on $\mathrm{GABA}_{A}$ receptors (26). According to the literature, some of these constituents, such as $\alpha$-pinene (33), nerolidol (34), linalool $(34,35)$, borneol (36), and viridiflorol (37) are positive modulators of $\mathrm{GABA}_{A}$ receptors. This result was also observed for EO1

\section{References}

1. Muench B. Quinaldine, a new anesthetic for fish. Prog FishCult 1958; 20: 42-44.

2. Amend DF, Goven BA, Elliot DG. Etomidate: effective dosages for a new fish anesthetic. Trans Am Fish Soc 1982; 111: 337-341.

3. Mattson NS, Ripple TH. Metomidate, a better anesthetic for cod (Gadus morhua) in comparison with benzocaine, MS222, chlorobutanol, and phenoxyethanol. Aquaculture 1989; 83: 89-94.

4. Gomes LC, Gomes ARC, Lopes NP, Roubach R, AraujoLima CARM. Efficacy of benzocaine as an anesthetic in juvenile tambaqui Colossoma macropomum. J World Aquac Soc 2001; 32: 426-431.

5. Okamoto MH, Tesser MB, Louzada LR, Santos RA, Sampaio LA. Benzocaine and eugenol as anaesthetics for pompano juvenile Trachinotus marginatus. Cienc Rural 2009; 39: 866870.

6. Sattari A, Mirzargar SS, Abrishamif A, Lourakzade R, Bahonar A, Mousavi HE, et al. Comparison of electroanesthesia with chemical anesthesia (MS-222 and clove oil) in rainbow trout (Oncorhynchus mykiss) using plasma cortisol and glucose responses as physiological stress indicators. Asian J Anim Vet Adv 2009; 4: 306-313.

7. Vale TG, Matos FJ, de Lima TC, Viana GS. Behavioral effects of essential oils from Lippia alba (Mill.) N.E. Brown chemotypes. J Ethnopharmacol 1999; 67: 127-133.

8. do Vale TG, Furtado EC, Santos JG Jr, Viana GS. Central effects of citral, myrcene and limonene, constituents of essential oil chemotypes from Lippia alba (Mill.) N.E. Brown. Phytomedicine 2002; 9: 709-714.

9. Cunha MA, Barros FMC, Garcia LO, Veeck APL, Heinzmann and EO2, which contain these substances, as shown in Table 1. However, given that EOs are complex mixtures of components and that some of their constituents can act by synergism, more studies are necessary to discover the active compound(s) responsible for the anesthetic effect of $L$. alba EO.

We showed for the first time the effect of BDZ on the potentiation of the anesthetic effects of EO in silver catfish. In addition, the anesthetic effects of the EO of $L$. alba were reversed sooner by flumazenil, suggesting the involvement of the GABAergic system in this effect of the EO.

\section{Acknowledgments}

The authors would like to thank Gilberto D. Zanetti (Department of Industrial Pharmacy, UFSM) for the botanical identification of $L$. alba. Research supported by FAPERGS/PRONEX (process \#10/0016-8) and CNPq (process \#470964/2009-0). B. Baldisserotto and M.E. Bürger are recipients of research fellowships from CNPq; C.G. Heldwein, L.L. Silva and P. Reckziegel are recipients of graduate fellowships from CAPES.

BM, Loro VL, et al. Essential oil of Lippia alba: a new anesthetic for silver catfish, Rhamdia quelen. Aquaculture 2010; 306: 403-406.

10. Sieghart W. Structure, pharmacology, and function of GABAA receptor subtypes. Adv Pharmacol 2006; 54: 231263.

11. Tanelian DL, Kosek P, Mody I, Maclver MB. The role of the GABAA receptor/chloride channel complex in anesthesia. Anesthesiology 1993; 78: 757-776.

12. Alexander SP, Mathie A, Peters JA. Guide to Receptors and Channels (GRAC). 3rd edn. Br J Pharmacol 2008; 153 (Suppl 2): S1-S209.

13. Delgado L, Schmachtenberg O. Immunohistochemical localization of GABA, GAD65, and the receptor subunits GABAAalpha1 and GABAB1 in the zebrafish cerebellum. Cerebellum 2008; 7: 444-450.

14. Kim YJ, Nam RH, Yoo YM, Lee CJ. Identification and functional evidence of GABAergic neurons in parts of the brain of adult zebrafish (Danio rerio). Neurosci Lett 2004; 355: 29-32.

15. Anonymous. European Pharmacopeia. 6th edn. Strassbourg: European Directorate for the Quality of Medicines; 2007.

16. Anonymous. NIST/EPA/NIH mass spectral library and search/analysis programs. Hoboken: J. Wiley and Sons; 2002.

17. Adams RP. Identification of essential oil components by gas chromatography/quadrupole mass spectroscopy. Illinois: Allured Publishing Corporation; 2001.

18. Greenberg AE, Taras MJ, Rand MC. Standard methods for the examination of water and wastewater. 14th edn. Spring- 
field: Bru-El Graphic; 1976.

19. Schoettger RA, Julin M. Efficacy of MS-222 as an anesthetic on four salmonids. Invest Fish Contr 1967; 13: 1-15.

20. Frighetto N, Oliveira JG, Siani AC, Chagas KC. Lippia alba (Mill.) N.E. Br (Verbenaceae) as a source of linalool. J Essent Oil Res 1998; 10: 578-580.

21. Duarte MC, Figueira GM, Sartoratto A, Rehder VL, Delarmelina C. Anti-Candida activity of Brazilian medicinal plants. $J$ Ethnopharmacol 2005; 97: 305-311.

22. Onaivi ES, Maguire PA, Tsai NF, Davies MF, Loew GH. Comparison of behavioral and central BDZ binding profile in three rat lines. Pharmacol Biochem Behav 1992; 43: 825-831.

23. Wolffgramm J, Mikolaiczyk C, Coper H. Acute and subchronic benzodiazepine-barbiturate-interactions on behaviour and physiological responses of the mouse. Naunyn Schmiedebergs Arch Pharmacol 1994; 349: 279-286.

24. Johnston GA, Hanrahan JR, Chebib M, Duke RK, Mewett $\mathrm{KN}$. Modulation of ionotropic GABA receptors by natural products of plant origin. Adv Pharmacol 2006; 54: 285316.

25. Neto AC, Netto JC, Pereira PS, Pereira AM, Taleb-Contini $\mathrm{SH}$, Franca SC, et al. The role of polar phytocomplexes on anticonvulsant effects of leaf extracts of Lippia alba (Mill.) N.E. Brown chemotypes. J Pharm Pharmacol 2009; 61: 933939.

26. Viana GS, do Vale TG, Silva CM, Matos FJ. Anticonvulsant activity of essential oils and active principles from chemotypes of Lippia alba (Mill.) N.E. Brown. Biol Pharm Bull 2000; 23: 1314-1317.

27. Tassonyi E, Charpantier E, Muller D, Dumont L, Bertrand D. The role of nicotinic acetylcholine receptors in the mechanisms of anesthesia. Brain Res Bull 2002; 57: 133-150.

28. Buggy DJ, Nicol B, Rowbotham DJ, Lambert DG. Effects of intravenous anesthetic agents on glutamate release: a role for GABAA receptor-mediated inhibition. Anesthesiology 2000; 92: 1067-1073.

29. Umezu T. Anticonflict effects of plant-derived essential oils. Pharmacol Biochem Behav 1999; 64: 35-40.

30. Koo BS, Park KS, Ha JH, Park JH, Lim JC, Lee DU. Inhibitory effects of the fragrance inhalation of essential oil from Acorus gramineus on central nervous system. Biol Pharm Bull 2003; 26: 978-982.

31. Hossain SJ, Aoshima H, Koda H, Kiso Y. Fragrances in oolong tea that enhance the response of GABAA receptors. Biosci Biotechnol Biochem 2004; 68: 1842-1848.

32. Rakhshandah $\mathrm{H}$, Hosseini M. Potentiation of pentobarbital hypnosis by Rosa damascena in mice. Indian J Exp Biol 2006; 44: 910-912.

33. Aoshima $\mathrm{H}$, Hamamoto K. Potentiation of GABAA receptors expressed in Xenopus oocytes by perfume and phytoncid. Biosci Biotechnol Biochem 1999; 63: 743-748.

34. Hossain SJ, Hamamoto K, Aoshima H, Hara Y. Effects of tea components on the response of $\operatorname{GABA}(\mathrm{A})$ receptors expressed in Xenopus oocytes. J Agric Food Chem 2002; 50: 3954-3960.

35. Aoshima H, Takeda K, Okita Y, Hossain SJ, Koda H, Kiso Y. Effects of beer and hop on ionotropic gamma-aminobutyric acid receptors. J Agric Food Chem 2006; 54: 2514-2519.

36. Granger RE, Campbell EL, Johnston GA. (+)- And (-)-borneol: efficacious positive modulators of GABA action at human recombinant alpha1beta2gamma2L GABA(A) receptors. Biochem Pharmacol 2005; 69: 1101-1111.

37. Jäger AK, Almqvist JP, Vangsre SAK, Stafford GI, Adsersen A, Van Staden J. Compounds from Mentha aquatica with affinity to the GABA-benzodiazepine receptor. S Afr J Bot 2007; 73: 518-521. 